\title{
Sammenheng mellom forløsningsmetode og bekkenbunnssvikt
}

BAKGRUNN En normal vaginal fødsel kan innebære betydelige påkjenninger for bekkenbunnen. Vi presenterer en oversikt over kunnskapsstatus om vaginal fødsel som risikofaktor for inkontinens og urogenital descens sammenliknet med keisersnitt.

KUNNSKAPSGRUNNLAG Vi gjorde et litteratursøk i PubMed. Systematiske oversiktsartikler og metaanalyser ble vektlagt. Søket ble avsluttet i januar 2014. Vi inkluderte også artikler fra egne litteraturarkiv.

RESULTATER Keisersnitt ser ut til å beskytte mot urininkontinens sammenliknet med vaginal fødsel, men effekten avtar når kvinnen kommer opp i 50-årene. Det er økt risiko for urogenital descens (dose-respons-effekt) med økende antall vaginalfødsler sammenliknet med keisersnitt. Det finnes få gode studier om sammenhengen mellom forløsningsmetode og analinkontinens, men metaanalyser kan tyde på at keisersnitt ikke beskytter etter postpartumperioden. Kvinner med tidligere sfinkterruptur ved vaginal fødsel er en undergruppe med økt risiko for analinkontinens. Alvorlighetsgraden av bekkenbunnssvikt er ofte ikke rapportert i litteraturen.

FORTOLKNING Forekomsten av urininkontinens og urogenital descens er lavere hos kvinner som kun er blitt forløst med keisersnitt sammenliknet med forekomsten hos dem som har født vaginalt. For urininkontinens er dette en forskjell som ser ut til å utjevnes med $\emptyset$ kende alder. Det er ikke grunnlag for å identifisere undergrupper med høy risiko for bekkenbunnsskader, unntaket er kvinner som tidligere har hatt sfinkterruptur. Keisersnitt vil ha begrenset primærforebyggende effekt på bekkenbunnssvikt på befolkningsnivå.

Urininkontinens, analinkontinens og descensus urogenitalis (fremfall) kan samlet kalles bekkenbunnssvikt. International Continence Society har etablert en standardisert terminologi for disse tilstandene. Den er nå i utbredt bruk forskningsmessig (1). Forekomst av disse tilstandene er først og fremst undersøkt i høyinntektsland (tab 1) (2). Det finnes betydelig grad av overlapping mellom tilstandene $(2,3)$, men det er forskjellige risikofaktorer.

Det er vanlig å anta at bekkenbunnssvikt delvis skyldes skader i forbindelse med vaginal fødsel. Andelen keisersnitt har økt betydelig $\mathrm{i}$ høyinntektsland de siste årene (4), i Norge fra knapt 2\% i 1967 til $17 \%$ i 2010 (5). Det er imidlertid store forskjeller mellom landene. For eksempel var keisersnittsandelen $24 \%$ i Storbritannia og $14 \%$ i Nederland i 2011 (6). Ved to av våre største fødeinstitusjoner, Oslo universitetssykehus,

Tabell 1 Forekomst av symptomer på bekkenbunnssvikt blant kvinner (2)

\begin{tabular}{lc} 
Symptom & Forekomst (\%) \\
Urininkontinens & $25-45$ \\
Analinkontinens $^{1}$ & $11-15$ \\
Urogenital descens & $5-10$ \\
\hline
\end{tabular}

Analinkontinens innbefatter lekkasje av luft eller flytende eller fast avføring
Ullevål, og Haukeland universitetssykehus, utgjorde keisersnitt henholdsvis $18,3 \%$ og $13,6 \%$ av fødslene i 2013 , mens landsgjennomsnittet lå på 16,4\% (5). Slike forskjeller tyder på at det ikke bare er objektive medisinske forhold som bestemmer keisersnittsandelen, det må også være kulturforskjeller mellom institusjonene og i samfunnet ellers (7).

Vi har gjennomgått litteratur om vaginal fødsel som risikofaktor for bekkenbunnssvikt sammenliknet med keisersnitt.

\section{Kunnskapsgrunnlag}

Vi gjorde søk i PubMed i engelskspråklig litteratur, sist oppdatert i januar 2014 (fig 1). Fordi vi ville undersøke risikoen etter keisersnitt under sammenliknbare forhold, inkluderte vi ikke artikler med materiale fra lavinntekts- og mellominntektsland med andre forutsetninger og rammer for fødselshjelpen enn i høyinntektsland. Artikler basert på selekterte populasjoner ble ekskludert. Der det var flere artikler basert på samme materiale (duplikasjoner), ble disse også utelatt.

Vi søkte ikke primært på systematiske oversiktsartikler og metaanalyser, men vektlegger funn fra sju slike $i$ våre analyser, da man i denne typen studier har kvalitetsvurdert underliggende studier og oppsummerer relevante resultat fra større populasjoner. Studier som ikke inngår i slike artikler er gjengitt summarisk, med tanke på om de

\author{
Guri Rørtveit \\ guri.rortveit@igs.uib.no \\ Allmennmedisinsk forskningsenhet i Bergen \\ Uni Research Helse \\ og \\ Forskningsgruppe for allmennmedisin \\ Institutt for global helse og samfunnsmedisin \\ Universitetet i Bergen \\ Yngvild S. Hannestad \\ Forskningsgruppe for allmennmedisin \\ Institutt for global helse og samfunnsmedisin \\ Universitetet i Bergen \\ Se også kunnskapsprøve \\ på www.tidsskriftet.no/quiz \\ Engelsk oversettelse på www.tidsskriftet.no
}

\section{HOVEDBUDSKAP}

Forekomsten av urininkontinens og urogenital descens er lavere hos kvinner som kun er blitt forløst med keisersnitt enn hos dem som har født vaginalt

Det er ikke grunnlag for å identifisere undergrupper med høy risiko for bekkenbunnsskader, unntaket er kvinner som tidligere har hatt sfinkterruptur

Keisersnitt vil ha begrenset primærforebyggende effekt på bekkenbunnssvikt på befolkningsnivå 
støtter eller motsier funnene fra metaanalysene og de systematiske oversiktsartiklene. I noen tilfeller er slike studier blitt publisert etter oversiktsartikkelen, mens andre studier er tatt med her fordi de tilfører informasjon med rimelig grad av metodologisk kvalitet.

Randomiserte studier er mangelvare, ettersom det ikke er etisk forsvarlig å behandle vaginal fødsel og keisersnitt som likeverdige metoder i de aller fleste tilfeller. Andre kvalitetstegn som vi la vekt på, var størrelse på studiepopulasjon, bruk av validerte instrumenter for å måle utfall, klassifisering av alvorlighetsgrad av de forskjellige tilstandene og informasjon om og eventuelt justering for relevante konfunderende faktorer.

Resultatet av søket er beskrevet i figur 1 . Det var stor heterogenitet i studiene, og vi fant det derfor ikke hensiktsmessig å reanalysere rådataene.

\section{Urininkontinens}

I en systematisk oversiktsartikkel der underlagstallene var reanalysert, ble det anslått at forekomsten av urininkontinens tre måneder post partum i gjennomsnitt er $30 \%$ hos kvinner med spontan vaginal fødsel, mens tilsvarende tall for kvinner som ble forløst med keisersnitt er $15 \%$ (8). Dette støttes av andre studier $(9,10)$.

Hvordan ser dette ut etter postpartumperioden? Prevalensen av stressinkontinens blir i en oversiktsartikkel anslått til $23 \%$ hos vaginalt fødende, mot $10 \%$ i keisersnittsgruppen mer enn ett år etter fødselen (11). En rekke enkeltstudier støtter disse funnene (12-30). En studie med 4200 kvinner gjort seks år etter fødselen viste at de som hadde født kun vaginalt og de som hadde født både vaginalt og via keisersnitt hadde omtrent lik forekomst av urinlekkasje (henholdsvis $26 \%$ og $28 \%$ ) (14). Derimot var det hos dem som hadde født kun med keisersnitt en forekomst på $14 \%$. Tilsvarende fant vi hos 15300 norske kvinner en forekomst på $24 \%$ av urinlekkasjene i gruppen som hadde født kun vaginalt og en forekomst på $16 \%$ i keisersnittsgruppen (15).

I flere studier rapporteres forskjeller mellom gruppene, men disse har ikke statistisk styrke til å påvise effekt på grunn av for få inkluderte eller for stort aldersspenn mellom deltakerne (31-36). The Term Breech Trial er den eneste randomiserte, kontrollerte studien på fødselsmetode (8). Denne behandler vi her som en observasjonsstudie på grunn av betydelig overkrysning mellom de randomiserte gruppene. To år etter fødselen var det ingen signifikant forskjell mellom gruppene med henblikk på urinlekkasje når de ble analysert slik de var randomisert (intention to treat), mens forskjellen mellom gruppene som kvinnene faktisk endte $i$, var på hele $9 \%$ (26\% inkontinente i vaginal fød-

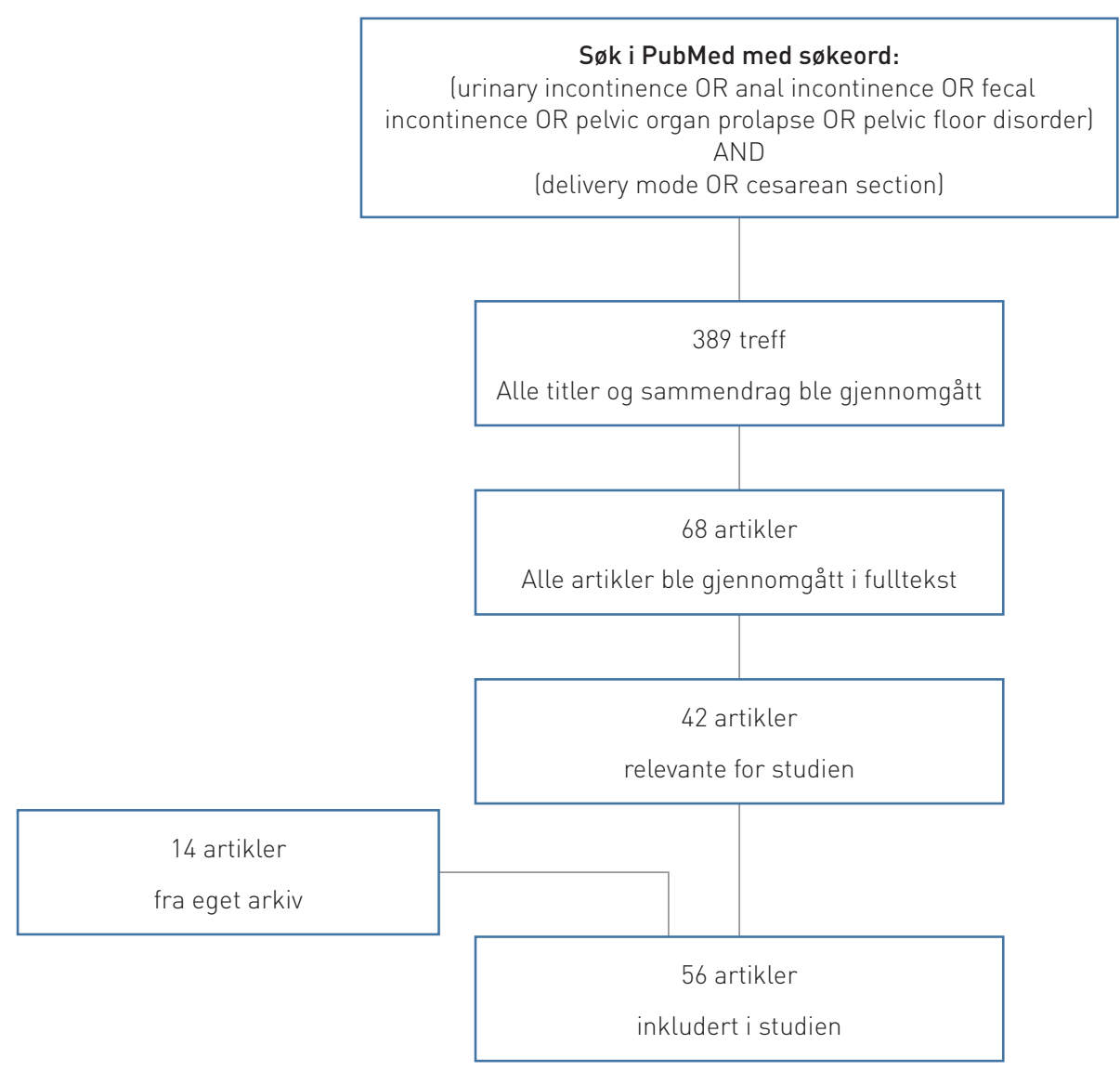

Figur 1 Oversikt over litteratursøk

sel-gruppen og $17 \%$ i keisersnittsgruppen) (37).

Når det gjelder alvorlighetsgrad, ble det $\mathrm{i}$ en av de systematiske oversiktsartiklene rapportert at forekomsten av alvorlig stressinkontinens ikke var signifikant forskjellig mellom gruppene $(2,0 \%$ i vaginal fødselgruppen versus $1,7 \%$ i keisersnittsgruppen) (11). I en studie fra Sverige fant man imidlertid at vaginal fødsel ga en hasardratio på $3,1(95 \% \mathrm{KI} 2,5-3,8)$ for senere operasjon for stressinkontinens sammenliknet med keisersnitt (38).

En rekke faktorer kan svekke eller forsterke sammenhengen mellom forløsningsmetode og urininkontinens. En viktig faktor er, som nevnt over, kvinnens alder på undersøkelsestidspunktet. I EPINCONT-studien fant vi at kvinner over 50 år ikke lenger hadde noen beskyttende effekt av å være blitt forløst med keisersnitt i alle sine fødsler (15). Dette gjaldt også for moderat og alvorlig inkontinens. Disse funnene er senere bekreftet av andre $(12,39)$.

Andre faktorer som kan spille negativt inn, er høy alder ved første fødsel (40) og å være førstegangsfødende (41). En kvinne må antakelig føde alle sine barn med keisersnitt for å oppnå beskyttelse mot langsiktig inkontinens $(14,23)$. Inkontinens i svangerskapet gir økt risiko for senere inkontinens, både $\mathrm{i}$ barselperioden og senere i livet $(9,18$, $21,42)$, men dette er likevel ikke en faktor som predikerer nytte av å føde med keisersnitt for å beskytte mot urinlekkasje $(9,43)$.

\section{Analinkontinens}

For analinkontinens er resultatene mindre klare. Metaanalyser er vanskelig å utføre på grunn av store forskjeller studier imellom når det gjelder forekomst av analinkontinens og datainnhentingsmetodikk (44).

Korttidseffektene av forløsningsmetoden i det første året etter fødselen ble undersøkt $i$ en metaanalyse (45). Her fant man en signifikant oddsratio for analinkontinens på 1,3 (95\% KI 1,04-1,7) ved spontan fødsel sammenliknet med keisersnitt. En enkeltstudie støtter denne konklusjonen (29). I flere andre enkeltstudier fant man imidlertid ikke forskjeller mellom de to gruppene i barselperioden $(33,46,47)$.

Når det gjelder varige konsekvenser, er det ikke overbevisende forskjeller mellom de to forløsningsmetodene. I en kohortstudie med nesten 4000 kvinner fant man ingen signifikant forskjell i forekomst av fekal inkontinens ut fra forløsningsmetode verken 


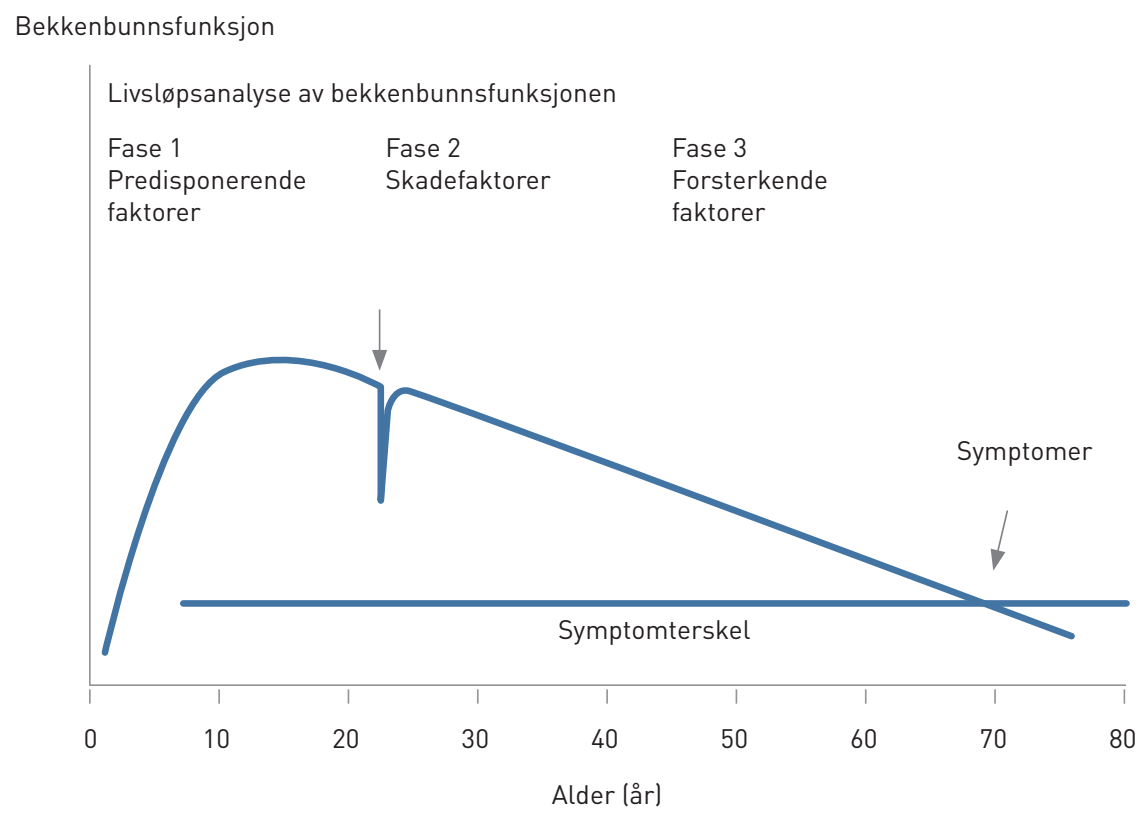

Figur 2 Bekkenbunnen i et livsløpsperspektiv, med påvirkning fra ulike faktorer i ulike faser. Fase 1: Predisponerende faktorer (bl.a. arv). Fase 2: Skadefaktorer i forbindelse med fødsel på grunn av anatomiske forhold (stort barn, bekkenfasong, leie) eller forløsningsfaktorer loperativ forløsning, lang trykketid). Fase 3: Forsterkende faktorer laldring, overvekt, fysisk aktivitet). Gjengitt med tillatelse fra Delancey og medarbeidere (78)

Bekkenbunnsfunksjon

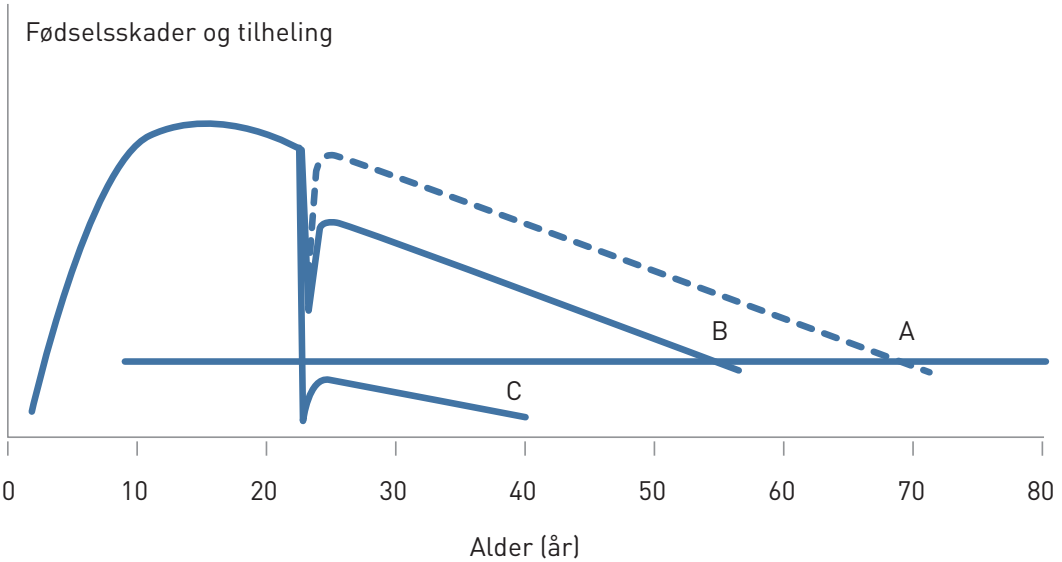

Bekkenbunnsfunksjon

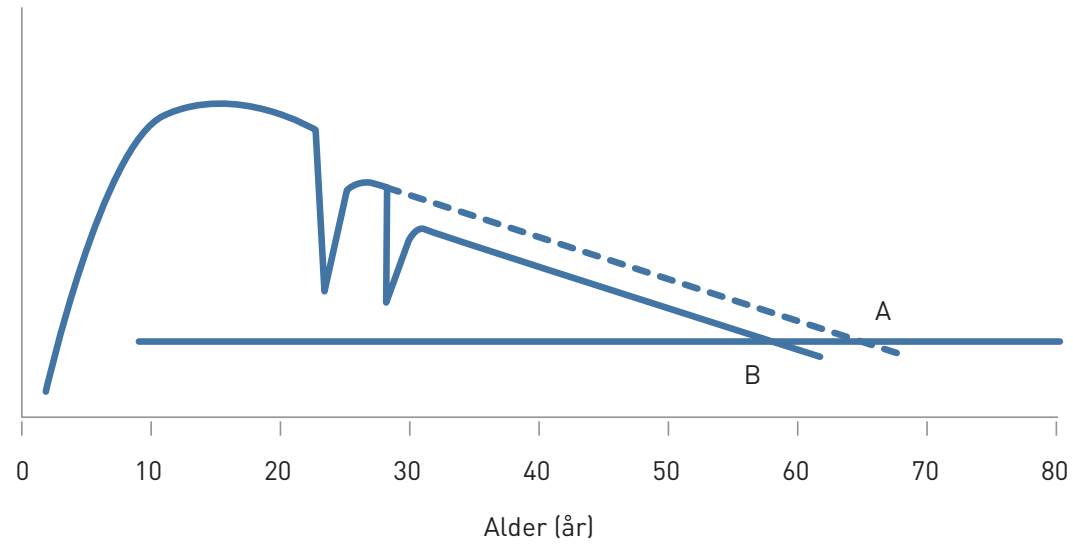

Figur 3 Variasjoner i fødselsskader og tilheling. I øverste del av figuren ser vi at en fødsel som ikke skader strukturer utover kroppens mulighet til å reparere seg selv (A), trenger ikke føre til utvikling av symptomer senere i livet. En større skade (B) som bare delvis tilheles, kan nedsette de funksjonelle reservene og gi symptomer tidligere enn de ville vært der uten skaden. Alvorlig skade (C) kan gi umiddelbare problemer som ikke til heles og føre til symptomer som ikke går tilbake. En ny fødsel (nedre del av figuren) kan påvirke hvor fort bekkenbunnsfunksjonen taper seg. Dette kommer an på graden av kumulativ skade. Gjengitt med tillatelse fra Delancey og medarbeidere (78) seks år eller 12 år etter fødselen $(23,48)$. Konklusjonen er den samme i flere andre studier $(13,22,24,37,49)$. Det finnes studier som tyder på at keisersnitt kan beskytte mot fekal eller analinkontinens utover postpartumperioden, men de er i fåtall (20) og har ofte metodologiske mangler, for eksempel lav statistisk styrke slik at funnene ikke var signifikante $(25,50,51)$.

Et sentralt spørsmål når det gjelder analinkontinens, er om det primært er undergruppen med sfinkterruptur som kan være utsatt. I en norsk studie av kvinner med sfinkterruptur etter fødselen var forekomsten av analinkontinens $38 \%$ (52). Et vesentlig problem både forskningsmessig og klinisk er at diagnostikk og registrering av sfinkterruptur kan være av varierende kvalitet.

En systematisk oversiktsartikkel konkluderte med at tredje eller fjerde grads perinealruptur (dvs. sfinkterruptur) var eneste etiologiske fødselsfaktor som var klart assosiert med analinkontinens (53). I en studie der man undersøkte fekal inkontinens, var forekomsten lik i keisersnittsgruppen og i gruppen som hadde født vaginalt uten klinisk diagnostisert sfinkterruptur $(8 \%$ i begge grupper) (33). Derimot var forekomsten signifikant høyere i en gruppe kvinner med sfinkterruptur etter vaginal fødsel $(17 \%)$. Andre studier tyder også på at vaginal fødsel i seg selv ikke er en risikofaktor for analinkontinens dersom analsfinkteren er uskadet (54-56).

Obstetriske faktorer kan ha betydning for sammenhengen mellom forløsningsmetode og analinkontinens. Episiotomi bør antakelig ikke gjøres rutinemessig (54, 57-60). Instrumentell vaginal forløsning med tang eller vakuum øker faren for sfinkterruptur (54, 61-64) og dermed risikoen for analinkontinens $(54,65)$. En norsk studie viser at sfinkterskade i den første fødselen gir en oddsratio på 4,3 (95\% KI 3,8-4,8) for ny sfinkterskade i neste fødsel (66).

\section{Descensus urogenitalis}

De fleste studier tyder på at keisersnitt beskytter mot descens både på kort $(67,68)$ og på lang sikt $(20,24,35,38,69-72)$, mens i en dansk registerbasert studie ble det ikke funnet noen forskjell (73).

En stor multisenterstudie rapporterte signifikant mindre anatomisk descens (målt ved standardiserte metoder ved gynekologisk undersøkelse) hos kvinner som hadde født kun med keisersnitt sammenliknet med dem som hadde født kun vaginalt (oddsratio 0,11;95\% KI 0,03-0,38) (71). Når det gjaldt rapporterte symptomer på fremfall var det samme tendens, men funnene her var ikke signifikante (oddsratio 0,84; $95 \% \mathrm{KI}$ 0,69-1,02) (71). Disse funnene støttes av 
andre $(24,38,69)$. Flere studier tyder på en dose-respons-effekt av vaginal fødsel på risikoen for fremfall $(38,69-71,74)$. Effekten ser ikke ut til å avta i høyere aldersgrupper (38).

\section{Diskusjon}

Den samlede forskningen tyder på at keisersnitt kan beskytte mot urininkontinens hos kvinner i fertil alder, men effekten vedvarer ikke når kvinnene blir eldre og forekomsten av inkontinens er høyest. For analinkontinens er det først og fremst sfinkterruptur som har betydning, ikke den vaginale fødselen per se. Strategier for å forebygge slike rupturer er langt viktigere enn å bruke keisersnitt for å unngå analinkontinens. Risikoen for urogenital descens etter vaginal fødsel er godt dokumentert. Her ser vi også en dose-respons-effekt av antall barn.

Kunnskap om hvordan bekkenbunnssvikt oppstår er nyttig for utvikling av forebyggingsstrategier og behandling. Keisersnitt $i$ seg selv kan neppe kalles en god forebyggingsstrategi, ettersom dette inngrepet fortsatt har mange negative konsekvenser for mor og barn $(37,75)$. Derimot er bekkenbunnstrening godt dokumentert som forebygging av urinlekkasje og ser også ut til å ha effekt på fremfallssymptomer, og både de økonomiske og de medisinske kostnadene ved slik behandling er lave $(76,77)$.

Mange faktorer spiller sammen i utviklingen av bekkenbunnssvikt, plager kan endres over tid og variere med livsstilsfaktorer og andre sykdommer. Det komplekse samspillet er pedagogisk demonstrert av Delancey og medarbeidere (fig 2, fig 3) (78).

Det har skjedd betydelige endringer $i$ indikasjon for keisersnitt de siste 30-40 år. Økende overvekt (også blant gravide) og økende alder ved første fødsel har betydning for utvikling av bekkenbunnssvikt. Hvordan forløsningsmetoden virker inn i forhold til dette, er ikke klart ennå.

Det er argumentert for at en optimal keisersnittsrate ligger på rundt $10-12 \%$, basert på en balanse mellom risiko og fordeler for både mor og barn (79). I de fleste høyinntektsland ligger man over dette nivået $\mathrm{i}$ dag, og keisersnittsandelen er stigende. I et globalt perspektiv bør innsatsen for å bedre mødrehelsen prioriteres i land der tilgangen til fødselshjelp (herunder nødvendige keisersnitt) er lav. Videreutvikling av metoder for fødselshjelp i høyinntektsland, for eksempel for å hindre sfinkterrupturer, er strategier som også vil ha nytte for kvinner i lavinntektsland.

Vår søkestrategi tilfredsstiller ikke strikte krav til en systematisk oversiktsartikkel. Vi mener likevel at litteraturen på feltet er godt dekket i denne oversikten. Den viktigste svakheten ved vår studie er den varierende kvaliteten på de underliggende data. Selv om epidemiologiske studier på feltet er blitt metodologisk langt bedre de siste ti år, er det fortsatt en rekke utfordringer - ikke minst når det gjelder definisjon og registrering av de tilstandene det er snakk om. Det er også en betydelig variasjon $i$ alvorlighetsgrad ved de tre tilstandene som vi her diskuterer. I mange studier skilles det dårlig mellom lette symptomer man kan leve greit med og behandlingstrengende tilstander.

\section{Konklusjon}

En normal vaginal fødsel innebærer betydelige påkjenninger på bekkenbunnen og fører til at en del kvinner i fertil alder utvikler urininkontinens. I enda større grad er vaginal fødsel en risikofaktor for genital descens. Vaginal fødsel uten sfinkterruptur øker trolig ikke risikoen for analinkontinens.

Keisersnitt som primærforebygging på befolkningsnivå har neppe en nytteverdi som står i forhold til innsatsen og de negative konsekvensene. Vi har ikke gode nok data til å kunne plukke ut undergrupper med høy risiko for bekkenbunnsskader - de som kunne ha nytte av å bli forløst med keisersnitt.

\section{Guri Rørtveit (f. 1965)}

er dr.med., spesialist i allmennmedisin, forskningsleder og professor. Hennes doktorgrad omhandlet sammenhengen mellom svangerskap og fødsler ved urininkontinens.

Forfatter har fylt ut ICMJE-skjemaet og oppgir ingen interessekonflikter.

\section{Yngvild Hannestad (f. 1968)}

er dr.med. og spesialist i fødselshjelp og kvinnesykdommer. Hennes doktorgrad omhandlet forekomst og risikofaktorer ved urininkontinens.

Forfatter har fylt ut ICMJE-skjemaet og oppgir ingen interessekonflikter.

\section{Litteratur}

1. Abrams P, Cardozo L, Wein A. The International Consultation on Incontinence, Research Society (ICI-RS). Neurourol Urodyn 2010; 29: 596-7.

2. Abrams P, Cardozo L, Khoury S et al. Incontinence. Paris: $\mid \mathrm{Cl}$; 2009

3. Rortveit G, Subak LL, Thom DH et al. Urinary incontinence, fecal incontinence and pelvic organ prolapse in a population-based, racially diverse cohort: prevalence and risk factors. Female Pelvic Med Reconstr Surg 2010; 16: 278-83.

4. D'Souza R, Arulkumaran S. To 'C' or not to 'C'? Caesarean delivery upon maternal request: a review of facts, figures and guidelines. J Perinat Med 2013; 41: 5-15.

5. Medisinsk fødselsregister, statistikkbank. Bergen Folkehelseinstituttet, 2012

6. Health at a glance 2011: OECD indicators. www.oecd-ilibrary.org/sites/health glance-2011en/04/09/g4-09-02.html?itemld=/content/chapter/ health_glance-2011-37-en (21.2.2014).
7. Tollånes MC. Økt forekomst av keisersnitt - årsaker og konsekvenser. Tidsskr Nor Legeforen 2009; 129: 1329-31.

8. Thom DH, Rortveit G. Prevalence of postpartum urinary incontinence: a systematic review. Acta Obstet Gynecol Scand 2010; 89: 1511-22.

9. Wesnes SL, Hunskaar S, Bo K et al. The effect of urinary incontinence status during pregnancy and delivery mode on incontinence postpartum. A cohort study. BJOG 2009; 116: 700-7.

10. Boyles SH, Li H, Mori T et al. Effect of mode of delivery on the incidence of urinary incontinence in primiparous women. Obstet Gynecol 2009; 113: 134-41.

11. Press JZ, Klein MC, Kaczorowski J et al. Does cesarean section reduce postpartum urinary incontinence? A systematic review. Birth 2007. 34: 228-37.

12. Connolly TJ, Litman HJ, Tennstedt SL et al. The effect of mode of delivery, parity, and birth weight on risk of urinary incontinence. Int Urogynecol J Pelvic Floor Dysfunct 2007; 18: 1033-42.

13. Dolan LM, Hilton P. Obstetric risk factors and pelvic floor dysfunction 20 years after first delivery. Int Urogynecol J 2010; 21: 535-44.

14. MacArthur C, Glazener CM, Wilson PD et al. Persistent urinary incontinence and delivery mode history: a six-year longitudinal study. BJOG 2006 113: $218-24$

15. Rortveit G, Daltveit AK, Hannestad YS et al. Urinary incontinence after vaginal delivery or cesarean section. N Engl J Med 2003; 348: $900-7$

16. Foldspang A, Hvidman L, Mommsen S et al. Risk of postpartum urinary incontinence associated with pregnancy and mode of delivery. Acta Obstet Gynecol Scand 2004; 83: $923-7$.

17. Goldberg RP, Abramov Y, Botros S et al. Delivery mode is a major environmental determinant of stress urinary incontinence: results of the Evanston-Northwestern Twin Sisters Study. Am J Obstet Gynecol 2005; 193: 2149-53.

18. Viktrup L, Rortveit G, Lose G. Risk of stress urinary incontinence twelve years after the first pregnancy and delivery. Obstet Gynecol 2006: 108: 248-54.

19. Diez-Itza I, Arrue M, Ibañez L et al. Factors involved in stress urinary incontinence 1 year after first delivery. Int Urogynecol J 2010; 21: 439-45.

20. Lukacz ES, Lawrence JM, Contreras R et al. Parity, mode of delivery, and pelvic floor disorders. Obstet Gynecol 2006; 107: 1253-60.

21. Ekström A, Altman D, Wiklund I et al. Planned cesarean section versus planned vaginal delivery: comparison of lower urinary tract symptoms. Int Urogynecol J Pelvic Floor Dysfunct 2008; 19: 459-65.

22. Altman D, Ekstrom A, Forsgren $C$ et al. Symptoms of anal and urinary incontinence following cesarean section or spontaneous vaginal delivery. Am J Obstet Gynecol 2007; 197: 512.e1-7.

23. MacArthur C, Glazener C, Lancashire R et al. Exclusive caesarean section delivery and subsequent urinary and faecal incontinence: a 12-year longitudinal study. BJOG 2011; 118: 1001-7.

24. Handa VL, Blomquist JL, Knoepp LR et al. Pelvic floor disorders $5-10$ years after vaginal or cesarean childbirth. Obstet Gynecol 2011; 118: 777-84.

25. Griffiths A, Watermeyer S, Sidhu K et al. Female genital tract morbidity and sexual function following vaginal delivery or lower segment caesarean section. J Obstet Gynaecol 2006; 26: 645-9.

26. Thompson JF, Roberts CL, Currie M et al. Prevalence and persistence of health problems after childbirth: associations with parity and method of birth. Birth 2002; 29: 83-94

27. Wilson PD, Herbison RM, Herbison GP. Obstetric practice and the prevalence of urinary incontinence three months after delivery. Br J Obstet Gynaecol 1996; 103: 154-61.

28. Eason E, Labrecque M, Marcoux S et al. Effects of carrying a pregnancy and of method of delivery on urinary incontinence: a prospective cohort study. BMC Pregnancy Childbirth 2004; 4: 4.

29. Solans-Domènech $M$, Sánchez E, Espuña-Pons $M$. Urinary and anal incontinence during pregnancy 
and postpartum: incidence, severity, and risk factors. Obstet Gynecol 2010; 115: 618-28.

30. Gyhagen M, Bullarbo M, Nielsen TF et al. The prevalence of urinary incontinence 20 years after childbirth: a national cohort study in singleton primiparae after vaginal or caesarean delivery. BJOG 2013; 120: 144-51.

31. Kuh D, Cardozo L, Hardy R. Urinary incontinence in middle aged women: childhood enuresis and other lifetime risk factors in a British prospective cohort. J Epidemiol Community Health 1999; 53 : 453-8.

32. Samuelsson E, Victor A, Svärdsudd K. Determinants of urinary incontinence in a population of young and middle-aged women. Acta Obstet Gynecol Scand 2000; 79: 208-15.

33. Borello-France D, Burgio KL, Richter HE et al. Fecal and urinary incontinence in primiparous women. Obstet Gynecol 2006; 108: 863-72.

34. Chaliha C, Kalia V, Stanton SL et al. Antenata prediction of postpartum urinary and fecal incontinence. Obstet Gynecol 1999: 94: 689-94.

35. MacLennan AH, Taylor AW, Wilson DH et al. The prevalence of pelvic floor disorders and their relationship to gender, age, parity and mode of delivery. BJOG 2000; 107: 1460 -70.

36. Herrmann V, Scarpa K, Palma PC et al. Stress urinary incontinence 3 years after pregnancy: cor relation to mode of delivery and parity. Int Urogynecol J Pelvic Floor Dysfunct 2009: 20: $281-8$.

37. Hannah ME, Whyte H, Hannah WJ et al. Maternal outcomes at 2 years after planned cesarean section versus planned vaginal birth for breech presentation at term: the international randomized Term Breech Trial. Am J Obstet Gynecol 2004: 191: 917-27.

38. Leijonhufvud A, Lundholm C, Cnattingius $S$ et al. Risks of stress urinary incontinence and pelvic organ prolapse surgery in relation to mode of childbirth. Am J Obstet Gynecol 2011: 204 70.e1-7.

39. Fritel $X$, Ringa V, Varnoux $N$ et al. Mode of delivery and severe stress incontinence. a cross-sectional study among 2,625 perimenopausal women. BJOG 2005; 112: 1646-51.

40. Groutz A, Helpman L, Gold R et al. First vaginal delivery at an older age: Does it carry an extra risk for the development of stress urinary incontinence? Neurourol Urodyn 2007: 26: 779-82.

41. Rortveit G, Hannestad YS, Daltveit AK et al. Ageand type-dependent effects of parity on urinary incontinence: the Norwegian EPINCONT study. Obstet Gynecol 2001: 98: 1004-10.

42. Glazener CM, Herbison GP, MacArthur $C$ et al. New postnatal urinary incontinence: obstetric and other risk factors in primiparae. BJOG 2006 113: 208-17.

43. Arrue M, Diez-Itza I, Ibañez L et al. Factors involved in the persistence of stress urinary incontinence from pregnancy to 2 years post partum. Int J Gynaecol Obstet 2011; 115: 256-9.

44. Nelson RL, Furner SE, Westercamp M et al. Cesarean delivery for the prevention of anal incontinence. Cochrane Database Syst Rev 2010; 2: CD006756.

45. Pretlove SJ, Thompson PJ, Toozs-Hobson PM et al. Does the mode of delivery predispose women to anal incontinence in the first year postpartum? A comparative systematic review. BJOG 2008; 115 421-34.

46. Brincat C, Lewicky-Gaupp C, Patel D et al. Fecal incontinence in pregnancy and post partum. Int J Gynaecol Obstet 2009: 106: 236-8.

47. Brown SJ, Gartland D, Donath S et al. Fecal incontinence during the first 12 months postpartum: complex causal pathways and implications for clinical practice. Obstet Gynecol 2012; 119: 240-9.

48. Macarthur C. Glazener C. Lancashire R et al. Faecal incontinence and mode of first and subsequent delivery: a six-year longitudinal study. BJOG 2005; 112: 1075-82.

49. Fritel $X$, Ringa $V$, Varnoux $N$ et al. Mode of delivery and fecal incontinence at midlife: a study of 2,640 women in the Gazel cohort. Obstet Gynecol 2007; 110: $31-8$.

50. Abramov Y, Sand PK, Botros SM et al. Risk factors for female anal incontinence: new insight through the Evanston-Northwestern twin sisters study. Obstet Gynecol 2005; 106: 726-32.

51. McKinnie V, Swift SE, Wang W et al. The effect of pregnancy and mode of delivery on the prevalence of urinary and fecal incontinence. Am J Obstet Gynecol 2005; 193: 512-7, discussion 517-8.

52. Laine K, Skjeldestad FE, Sanda B et al. Prevalence and risk factors for anal incontinence after obstetric anal sphincter rupture. Acta Obstet Gynecol Scand 2011: 90: 319-24.

53. Bols EM, Hendriks EJ, Berghmans BC et al. A systematic review of etiological factors for postpartum fecal incontinence. Acta Obstet Gynecol Scand 2010; 89: 302-14.

54. Eason E, Labrecque M, Marcoux S et al. Anal incontinence after childbirth. CMAJ 2002; 166: 326-30

55. Lal M, H Mann C, Callender R et al. Does cesarean delivery prevent anal incontinence? Obstet Gyneco 2003: 101: 305-12.

56. Guise JM, Boyles SH, Osterweil P et al. Does cesa rean protect against fecal incontinence in primiparous women? Int Urogynecol J Pelvic Floor Dysfunct 2009: 20: 61-7.

57. Eason E, Labrecque M, Wells $G$ et al. Preventing perineal trauma during childbirth: a systematic review. Obstet Gynecol 2000; 95: 464-71.

58. Parant 0 , Simon-Toulza C, Cristini $C$ et al. Faecal incontinence after first instrumental vaginal delivery using Thierry's spatulas. Int Urogynecol J 2010; 21: 1195-203

59. Weber AM. Elective cesarean delivery: the pelvic perspective. Clin Obstet Gynecol 2007: 50: 510-7.

60. Carroli G. Mignini L. Episiotomy for vaginal birth. Cochrane Database Syst Rev 2009; 1: CD000081.

61. Baghestan E, Irgens LM, Børdahl PE et al. Trends in risk factors for obstetric anal sphincter injuries in Norway. Obstet Gynecol 2010; 116: 25-34.

62. Fitzgerald MP, Weber AM, Howden N et al. Risk factors for anal sphincter tear during vaginal delivery. Obstet Gynecol 2007; 109: 29-34.

63. Hehir MP, O'Connor HD, Higgins S et al. Obstetric anal sphincter injury, risk factors and method of delivery - an 8-year analysis across two tertiary referral centers. J Matern Fetal Neonatal Med 2013; 26: 1514-6
64. Macarthur C, Wilson D, Herbison P et al. Faecal incontinence persisting after childbirth: a 12 year longitudinal study. BJOG 2013; 120: 169-78.

65. Fenner D. Anal incontinence: relationship to pregnancy, vaginal delivery, and cesarean section Semin Perinatol 2006; 30: 261-6.

66. Spydslaug A, Trogstad LI, Skrondal A et al. Recurrent risk of anal sphincter laceration among women with vaginal deliveries. Obstet Gynecol 2005; 105: 307-13.

67. Diez-Itza I, Arrue M, Ibañez L et al. Influence of mode of delivery on pelvic organ support 6 months postpartum. Gynecol Obstet Invest 2011; 72: $123-9$

68. O'Boyle AL, O'Boyle JD, Calhoun B et al. Pelvic organ support in pregnancy and postpartum. In Urogynecol J Pelvic Floor Dysfunct 2005; 16: 69-72, discussion 72.

69. Larsson C, Kallen K, Andolf E. Cesarean section and risk of pelvic organ prolapse: a nested casecontrol study. Am J Obstet Gynecol 2009; 200: 243.e1-4

70. Rortveit G, Brown JS, Thom DH et al. Symptomatic pelvic organ prolapse: prevalence and risk factors in a population-based, racially diverse cohort. Obstet Gynecol 2007; 109: 1396-403

71. Glazener C, Elders A, Macarthur C et al. Childbirth and prolapse: long-term associations with the symptoms and objective measurement of pelvic organ prolapse. BJOG 2013; 120: 161-8.

72. Gyhagen M, Bullarbo M, Nielsen TF et al. Prevalence and risk factors for pelvic organ prolapse 20 years after childbirth: a national cohort study in singleton primiparae after vaginal or caesarean delivery. BJOG 2013: 120: 152-60.

73. Krebs L, Langhoff-Roos J. Elective cesarean delivery for term breech. Obstet Gynecol 2003; 101 : $690-6$.

74. Swift S, Woodman P, O'Boyle A et al. Pelvic Organ Support Study (POSST): the distribution, clinical definition, and epidemiologic condition of pelvic organ support defects. Am J Obstet Gynecol 2005 192: 795-806

75. Cesarean delivery on maternal request. Report. Washington D.C.: National Institutes of Health, 2006

76. Mørkved S, Bø K. Effect of postpartum pelvic floor muscle training in prevention and treatment of urinary incontinence: a one-year follow up. BJOG 2000; 107: 1022-8.

77. Hagen S, Stark D. Conservative prevention and management of pelvic organ prolapse in women. Cochrane Database Syst Rev 2011: 12: CD003882.

78. Delancey JO, Kane Low L, Miller JM et al. Graphic integration of causal factors of pelvic floor disorders: an integrated life span model. Am J Obstet Gynecol 2008; 199: 610.e1-5.

79. Joffe M, Chapple J, Paterson C et al. What is the optimal caesarean section rate? An outcome based study of existing variation. J Epidemiol Community Health 1994; 48: 406-11.

Mottatt 3.7. 2013, første revisjon innsendt 21.2. 2014, godkjent 12.9. 2014. Redaktør: Tor Rosness. 